\title{
Off-target effects of glycoprotein IIb/IIIa receptor inhibitors
}

\author{
Małgorzata Ostrowska ${ }^{1}$, Piotr Adamski ${ }^{1}$, Marek Koziński ${ }^{1}$, Eliano Pio Navarese ${ }^{2}$, \\ Tomasz Fabiszak ${ }^{2}$, Grzegorz Grześk ${ }^{2,3}$, Przemysław Paciorek ${ }^{4}$, Jacek Kubica ${ }^{2}$ \\ ${ }^{1}$ Department of Principles of Clinical Medicine, Collegium Medicum, \\ Nicolaus Copernicus University, Bydgoszcz, Poland \\ ${ }^{2}$ Department of Cardiology and Internal Medicine, Collegium Medicum, \\ Nicolaus Copernicus University, Bydgoszcz, Poland \\ ${ }^{3}$ Department of Pharmacology and Therapeutics, Collegium Medicum, \\ Nicolaus Copernicus University, Bydgoszcz, Poland \\ ${ }^{4}$ Department of Emergency Medicine, Collegium Medicum, \\ Nicolaus Copernicus University, Bydgoszcz, Poland
}

\begin{abstract}
Soon after identification of the platelet membrane glycoprotein (GP) IIb/IIIa, it has become a target of antiplatelet therapy. There are 3 intravenous GP IIb/IIIa receptor inhibitors, namely - eptifibatide, tirofiban and abciximab, used in the contemporary clinical practice, particularly in patients with acute coronary syndrome undergoing percutaneous coronary intervention (PCI). The aim of the current review is to summarize available knowledge concerning off-target effects of GP IIb/IIIa receptor inhibitors. All 3 drugs have similar antithrombotic properties, but differ with respect to pharmacodynamics, pharmacokinetics and off-target effects. Eptifibatide and tirofiban are highly specific GP IIb/III a receptor inhibitors, while abciximab is unselective and cross-reacts with integrin $\alpha v \beta 3-a$ vitronectin receptor and leukocyte-associated integrin Mac-1. As a result of these interactions, abciximab seems to reduce the development of clinical restenosis, decrease infarct size, inhibit adhesion of monocytes to medical steel and modulate the inflammatory response. Intracoronary administration of abciximab provides higher drug concentration in the target area, increasing dose-dependent interactions with other integrins. Off-target effects of small molecule GP IIb/IIIa receptor inhibitors (i.e. eptifibatide and tirofiban) are predominantly connected with their suppressive influence on the inflammatory response. All in all, although GP IIb/IIIa receptor inhibitors are not recommended as a routine therapy during PCI, their antiplatelet properties and potential off-target effects may be beneficial in certain subsets of patients. (Cardiol J 2014; 21, 5: 458-464)
\end{abstract}

Key words: abciximab, eptifibatide, tirofiban, GP IIb/IIIa receptor inhibitor, off-target effects, pleiotropic effects

Address for correspondence: Małgorzata Ostrowska, MD, Department of Principles of Clinical Medicine, ul. Skłodowskiej-Curie 9, 85-094 Bydgoszcz, Poland, tel: +48 5258540 23, fax: + 485258540 24, e-mail: ostrowska.go@gmail.com

Received: 07.08.2013 Accepted: 06.11.2013 


\section{Introduction}

The identification of the platelet membrane glycoprotein (GP) IIb/IIIa receptor was a milestone in the understanding of thrombus formation. Because of its key role in platelet aggregation, it has quickly become a target of antiplatelet therapy. In 1994, results of the EPIC trial demonstrated the efficacy of GP IIb/IIIa receptor blockade in reducing thrombotic complications in patients undergoing high risk percutaneous coronary interventions (PCIs) [1]. Within the next 5 years 3 intravenous GP IIb/IIIa receptor inhibitors (GPIs) were approved for clinical practice, particularly in patients treated with PCI due to acute coronary syndrome (ACS) [2-6]. These three drugs possess similar antiplatelet properties, but differ with respect to pharmacodynamics, pharmacokinetics and off-target effects (Table 1). According to the recent European guidelines on ST-segment elevation myocardial infarction, GPIs should be considered for bailout therapy if there is an angiographic evidence of massive thrombus, in case of slow flow or no-reflow or if a thrombotic complication occurs (class of recommendation IIa, level of evidence C) [6].

The aim of the current review is to summarize available knowledge concerning off-target effects of GPI.

A search covering the period from January 1993 to November 2013 was conducted by two independent investigators using MEDLINE, CENTRAL and Google Scholar databases. Proceedings from the Scientific Sessions of the American College of Cardiology (http://www.acc.org), American Heart Association (http://www.heart.org), the European Society of Cardiology (http://www.escardio. org), Transcatheter Cardiovascular Therapeutics (http://www.tctmd.com), and EuroPCR (http://www. europcr.com) were also considered. The following keywords were applied: "abciximab", "eptifibatide", "tirofiban”, "GP IIb/IIIa receptor inhibitor", “off-target effects". References of studies retrieved were searched manually for additional studies and reviews. No language restrictions were applied.

\section{Structure and role of the GP IIb/IIIa receptor}

It is well known that platelet aggregation and thrombus formation play a pivotal role in ACS [7-9]. The rupture of atherosclerotic plaque initiates platelet adhesion, which is followed by platelet activation, including conformational changes in platelet structure, such as activation of the GP IIb/ /IIIa receptors, and finally stimulation of platelet aggregation. The GP IIb/IIIa receptor belongs to the integrin family of adhesion molecules, composed of $\alpha$ and $\beta$ subunits (Fig. 1) [10]. After platelet activation, the GP IIb/IIIa receptor develops a high affinity for fibrinogen. The fibrinogen molecule has binding sites at both ends, allowing bridging between neighboring platelets, thus leading to thrombus formation [11]. GPI prevents the binding of fibrinogen to the adjacent GP IIb/IIIa receptors [12]. By this mechanism, the final common pathway of platelet aggregation is blocked. There are 3 intravenous GPIs that are used in everyday practice, namely abciximab (large molecule), and 2 small molecule agents - eptifibatide and tirofiban.

\section{Abciximab}

Abciximab is a part-murine, part-human chimeric Fab fragment of the monoclonal 7E3 IgG3

Table 1. Characteristics of intravenous glycoprotein Ilb/Illa inhibitors.

\begin{tabular}{|c|c|c|c|}
\hline & Abciximab & Eptifibatide & Tirofiban \\
\hline Type & $\begin{array}{l}\text { Monoclonal anti- } \\
\text { body fragment }\end{array}$ & Cyclic heptapeptide & $\begin{array}{c}\text { Non-peptide tyrosine } \\
\text { derivative }\end{array}$ \\
\hline Inhibition & Noncompetitive & Competitive & Competitive \\
\hline Platelet affinity & High & Low & Intermediate \\
\hline \multicolumn{4}{|l|}{ Standard dosage: } \\
\hline Bolus & $0.25 \mathrm{mg} / \mathrm{kg}$ & $180 \mu \mathrm{g} / \mathrm{kg}$ & - \\
\hline Infusion & $0.125 \mu \mathrm{g} / \mathrm{kg} / \mathrm{min}$ & $2 \mu \mathrm{g} / \mathrm{kg} / \mathrm{min}$ & $\begin{array}{c}0.4 \mu \mathrm{g} / \mathrm{kg} / \mathrm{min} \text { over } 30 \mathrm{~min}, \\
\text { next } 0.1 \mu \mathrm{g} / \mathrm{kg} / \mathrm{min}\end{array}$ \\
\hline Plasma half-life & $<10 \min$ & $2.5 \mathrm{~h}$ & $1.5 \mathrm{~h}$ \\
\hline Selectivity & Non-selective & Selective & Selective \\
\hline Route of elimination & Spleen & Renal & Renal and biliary \\
\hline Recovery of platelet function & $24-48 \mathrm{~h}$ & $4 \mathrm{~h}$ & $4 \mathrm{~h}$ \\
\hline Reversibility with platelets infusion & Yes & No & No \\
\hline
\end{tabular}




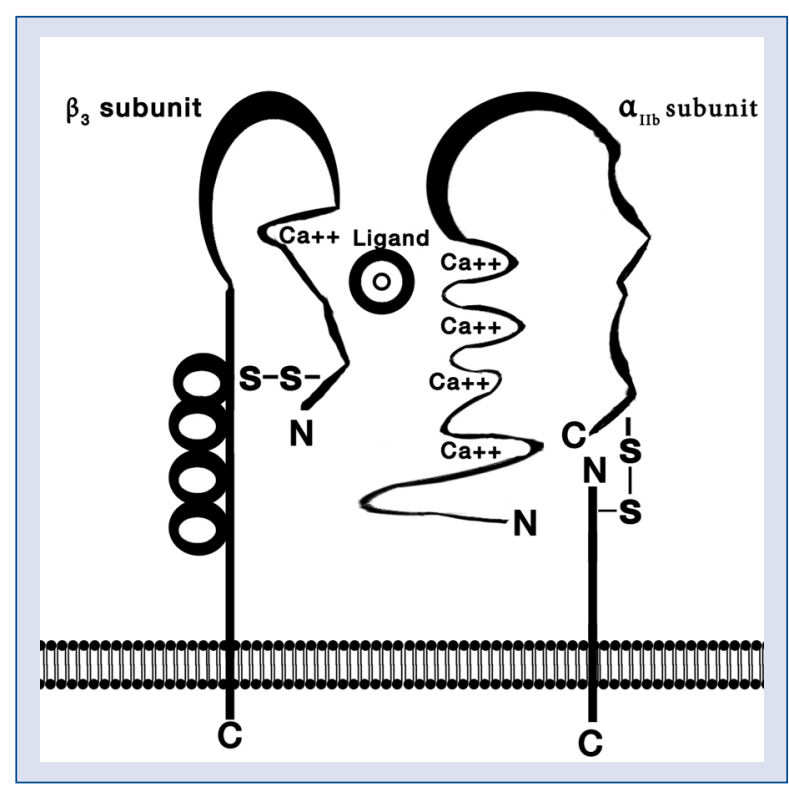

Figure 1. Glycoprotein Ilb/Illa receptor.

antibody against the GP IIb/IIIa receptor. Its structure is based on a murine monoclonal antibody, first described by Coller at al. [13, 14]. Abciximab is a competitive, reversible GP IIb/IIIa receptor inhibitor, which binds to platelets with very high affinity. It is characterized by a short plasma half-life due to its rapid binding to the platelet receptor. The binding site of abciximab is located on the $\beta 3$ chain of the GP IIb/IIIa receptor [15]. High local concentration of abciximab obtainable with intracoronary administration results in dissolution of existing platelet-rich thrombi and extensive dispersion of platelet aggregates, thus reducing distal microembolization [16-18]. The inhibition of platelet-induced thrombin generation observed with high concentration of abciximab is associated with a decreased release of platelet granules containing inhibitors of fibrinolysis such as plasminogen activator inhibitor-1 and $\alpha 2$-anti-plasmin [19]. The increased porosity of thrombus caused by c7E3 Fab allows penetration of endogenous fibrinolytic agents into the clot, thereby promoting spontaneous thrombolysis [18].

In contrast to small-molecule GPIs, abciximab is a non-selective GP IIb/IIIa receptor antagonist. Since the $\beta 3$ subunit is also present in integrin $\alpha \mathrm{v} \beta 3$, abciximab also binds to this cellular vitronectin receptor expressed on endothelial and smooth muscle cells, monocytes, polymorphonuclear leukocytes, and T lymphocytes [19-21]. Abciximab also cross-reacts with the leukocyte-associated integrin Mac-1 ( $\alpha \mathrm{M} \beta 2)$. Intracoronary administration producing high local concentration of abciximab may also enhance the non-GP IIb/IIIa properties of this agent that are mainly based on complex antiinflammatory interactions, with off-target effects of abciximab being their consequence.

The endothelial integrin $\alpha \mathrm{v} \beta 3$ can bind to several molecules such as fibrinogen, vitronectin, thrombospondin and prothrombin. It also causes endothelial adhesion of activated platelets and entrapment of leukocytes in the platelet-fibrin mesh. It is upregulated in case of ischemia, predominantly in small arterioles. As an antagonist of integrin $\alpha \mathrm{v} \beta 3$, abciximab may influence restenosis, a process of vessel re-narrowing after initially successful PCI. Detailed $\alpha v \beta 3$-mediated effects of abciximab, potentially preventing restenosis, include inhibition of smooth muscle cell (SMC) migration and proliferation, thrombin generation and clot retraction. SMC migration and proliferation initiate the process of restenosis [22]. In a study by Baron et al. [23], abciximab inhibited adhesion and migration of human SMC, while Stouffer et al. [24] described hindering influence of abciximab on SMC proliferation in a baboon model. Furthermore, an in vitro study showed abciximab to be a potent inhibitor of human coronary artery SMC migration and invasion [25]. Therefore, $\alpha \mathrm{v} \beta 3$-mediated effects of abciximab on the development of restenosis may explain the lower incidence of need for long-term recurrent coronary interventions in the EPIC trial [1]. In addition, the EPISTENT and ISAR-SWEET trials suggested a reduction in clinical restenosis in favor of abciximab in diabetic patients [26, 27]. Similar results were observed in a large Danish single-center registry [28]. In a meta-analysis by $\mathrm{Wu}$ et al. [29], a decreased 1-year target lesion revascularization risk was the only benefit from abciximab therapy. However, these promising long-term results were not confirmed in the ERASER, EPILOG and CAPTURE trials [2, 3, 30]. Moreover, the beneficial effects on restenosis from abciximab therapy present in diabetic patients receiving coronary bare metal stents were absent in diabetic patients undergoing elective drug-eluting stents implantation [31]. In the STRATEGY trial, the conjunction of tirofiban plus sirolimus-eluting stent was confronted with abciximab plus bare metal stent. The significantly lower occurrence of restenosis and the need for target vessel revascularization observed with tirofiban plus sirolimuseluting stent [32] suggest that reduction in clinical restenosis is less pronounced in patients treated with abciximab than in those receiving drug-eluting stents. The addition of tirofiban to sirolimus-eluting stent seemed to have no influence on restenosis. 
This was further confirmed in the ADVANCE trial, where the administration of high-dose bolus of tirofiban had no significant effect on target vessel revascularization [33].

Referring to an accumulating body of evidence on the influence of abciximab on restenosis, Kim et al. [34, 35] took another step ahead and tested abciximab-coated stents in the setting of stable coronary artery disease, as well as in acute myocardial infarction (AMI), proving abciximab-coated stents to be safe and effective in the prevention of coronary restenosis. Unfortunately, in a 2-year follow-up, abciximab-coated stents did not show superiority over bare metal stents [36]. Hong et al. [37] compared the anti-inflammatory effects of abciximab-coated stents, sirolimus-eluting stents, and paclitaxel-eluting stents in an animal coronary restenosis model. The results were comparable with respect to inhibition of inflammatory cell infiltration and neointimal hyperplasia in abciximab-coated stents and other drug-eluting stents.

Sakuma et al. [38] compared the effect of the combined blockade of the GP IIb/IIIa receptor and integrin $\alpha \mathrm{v} \beta 3$ with the blockade of GP IIb/IIIa receptor alone, using a highly specific inhibitor - tirofiban, relating the results to a control group receiving saline. They found that out of these 3, simultaneous inhibition of GP IIb/IIIa and integrin $\alpha \mathrm{v} \beta 3$ cause a marked reduction in infarct size, in a model of acute coronary thrombosis and primary PCI, which is associated with reduced myocardial microthrombi and inflammation, as well as improved myocardial blood flow and regional function [38]. Abciximab was not used in the study, but as far as we know, abciximab inhibits both - the GP $\mathrm{IIb} / \mathrm{III}$ receptor and integrin $\alpha \mathrm{v} \beta 3$, so we may assume that the effect would be similar.

The leukocyte $\beta 2$ integrin Mac- 1 is a pivotal adhesion molecule, involved in the interaction of neutrophils and monocytes with the microvasculature, limiting reperfusion in AMI [39-42]. In a study by Neumann et al. [43], increased platelet-leukocyte interaction in patients with AMI was observed. Importantly, the authors demonstrated that binding of activated platelets induces the release of interleukin- $1 \beta$, interleukin- 8 , and monocyte chemoattractant protein-1 in leukocytes. The study findings suggest that leukocyte-platelet adhesion contributes to the regulation of inflammatory responses in AMI. In another research, Neumann et al. [44] demonstrated that abciximab reduces Mac-1 surface expression and platelet-leukocyte interaction, by decreasing the platelet mass in platelet-monocyte aggregates.
According to Schuler et al. [45], the monocyte integrin receptor Mac-1 is a central mediator of monocyte adhesion to medical steel, for example metal stents. Since cell adhesion could be blocked by anti-Mac-1-antibodies, the cross-reacting anti-GP IIb/IIIa antibody fragment - abciximab may potentially inhibit monocyte adhesion to stents.

Schwarz et al. [46] found that abciximab not only binds to the leukocyte integrin Mac-1, but also inhibits binding of several distinct ligands and thereby may modulate inflammation, cell proliferation, and coagulation. The binding of fibrinogen, the inactivated complement factor $3 \mathrm{~b}$ and the coagulation factor $\mathrm{X}$ to Mac-1 was inhibited by abciximab in vitro. As a functional consequence, the conversion of factor $\mathrm{X}$ to factor Xa mediated by Mac-1 was impaired by abciximab. The adhesion of monocytic cell line to immobilized intercellular adhesion molecule 1 and to fibrinogen, ligands abundant in the injured vessel wall, was reduced significantly by abciximab [47]. Fibrinogen-mediated cell aggregation was also impaired. Overall, the inhibition of Mac-1 can provide additional clinical benefits of abciximab beyond the well-described blockade of GP IIb/IIIa.

Inflammation plays an important role in the progression of atherosclerosis [48]. Systemic markers of inflammation are increased in patients with ACS and usually rise within $24 \mathrm{~h}$ to $48 \mathrm{~h}$ after PCI $[49,50]$. Cross-reactions of abciximab with integrins $\alpha \mathrm{v} \beta 3$ and Mac- 1 are assumed to decrease the endothelial inflammatory reaction. In their study, Lincoff et al. [51] measured the concentration of C-reactive protein (CRP), interleukin- 6 and tumor necrosis factor $\alpha$ before and $24-48 \mathrm{~h}$ after PCI. They observed, that in patients receiving periprocedural abciximab, the magnitude of rise of the measured inflammatory markers was diminished, compared with patients receiving placebo [51].

Recently the topic of intracoronary use of abciximab has been extensively discussed in the literature [52-56]. This administration route seems to provide a much higher concentration of abciximab in the target area and possibly allow direct influence not only on the platelet GP IIb/IIIa receptor, but also on vitronectin and Mac-1 receptors, enhancing dose-dependent off-target effects of abciximab. Two independent small randomized trials showed intracoronary administration of abciximab to be associated with improved myocardial perfusion and smaller infarct size [57, 58].

A bolus of abciximab is usually administered through the guiding catheter into the infarct-related artery. This method does not assure an 
optimal effect of abciximab, with the rapid wash out by the coronary flow. Prati et al. [59] tested the effectiveness of local abciximab delivery to the site of IC thrombus vs. IC bolus infusion in patients with ACS undergoing PCI. For local IC delivery of abciximab a dedicated perfusion catheter was applied. This catheter enables local drug delivery to reach approximately a 500-fold higher drug concentration vs. systemic delivery. Significantly lower rates of procedure-related AMI and major adverse cardiac events at 1 year were observed in the local intracoronary infusion group. These results strongly suggest that the use of the dedicated perfusion catheter leads to higher concentrations of abciximab within the thrombus, allowing for an additional antiplatelet, antithrombotic, and anti-inflammatory effect [59].

Further efforts should be undertaken to define the benefits of super-selective local delivery of abciximab.

\section{Small molecular weight GPIs: Eptifibatide and tirofiban}

Eptifibatide is a cyclic heptapeptide modeled on the structure of barbourin - a disintegrin that contains a KGD aminoacid sequence, which provides this molecule with high specificity for binding to the GP IIb/IIIa receptor. Eptifibatide acts specifically on the $\alpha$ IIb chain of the GP IIb/ /IIIa receptor, which is a RGD binding site. It is a selective molecule for the GP IIb/IIIa receptor with very rapid association and dissociation kinetics concerning this receptor, while it shows no reactivity with other integrins. Eptifibatide is eliminated by the kidneys, with the most of it excreted as the unchanged drug in the urine.

Tirofiban is a non-peptide tyrosine derivative. Like eptifibatide, it is an antagonist against the RGD binding site on the $\alpha \mathrm{IIb}$ chain of the GP IIb/ /IIIa receptor [60]. It is also highly specific for the GP IIb/IIIa receptor and does not interact with other integrins. Tirofiban's affinity for the GP IIb/ /IIIa receptor is intermediate between abciximab and epitfibatide. It has also very rapid association and dissociation with the GP IIb/IIIa receptor. Tirofiban is removed by both renal and biliary excretion.

Both tirofiban and eptifibatide may exert anti-inflammatory effects. In a study by Azar et al. [61], in high risk patients undergoing PCI, tirofiban significantly suppressed the rise of high sensitivity CRP. In a paper by Walters et al. [62], the combination of high dose tirofiban with enoxaparin resulted in an attenuated inflammatory response compared with the combination of high dose tirofiban with unfractionated heparin. Ercan et al. [63] explain the anti-inflammatory effect of tirofiban with platelet inhibition, since products of activated platelets may aid neutrophil accumulation and enhance inflammation. Activated leukocytes and platelets mutually potentiate each others' effects. Tirofiban strongly inhibits the platelet aggregation. The decreased platelet aggregation can suppress the inflammatory proteins, chemokines, and the expression of adhesion molecules. In their study, CRP elevation was attenuated in patients with non-ST segment elevation myocardial infarction (NSTEMI) treated with tirofiban infusion. Ueland et al. [64] confirmed the potential of eptifibatide as anti-inflammatory drug able to down-regulate platelet-mediated inflammation. On the other hand, Mazaev et al. [65] failed to find any anti-inflammatory effects of eptifibatide in patients with unstable angina and NSTEMI.

\section{Summary}

All the 3 agents discussed are effective inhibitors of the GP IIb/IIIa receptor. However, the exact binding site of each agent is different, causing potentially different functional responses in platelets. In addition, these agents have different specificities for other integrins. Tirofiban and eptifibatide have been designed to inhibit the platelet GP IIb/IIIa receptor without cross-reacting with other integrins. In contrast, abciximab is non-specific, because it also blocks integrin $\alpha \mathrm{v} \beta 3$ and leukocyte-associated integrin Mac-1. As a result of these interactions, some of the clinical effects of abciximab, such as anti-inflammatory effects, reduction of clinical restenosis and infarct size, go beyond the consequences of its plain binding to the GP IIb/IIIa receptor. All in all, although GPIs are not recommended as a routine therapy during PCI, their antiplatelet properties and potential off-target effects may be beneficial in certain subsets of patients.

\section{Acknowledgements}

The present contribution is a project of Systematic Investigation and Research on Interventions and Outcomes (SIRIO)-MEDICINE, a group of senior scientists and fellows collaborating worldwide to pursue research and innovation in medicine.

\section{Conflict of interest: None declared}

\section{References}

1. EPIC Investigators. Use of a monoclonal antibody directed against the platelet glycoprotein IIb/IIIa receptor in high-risk coronary angioplasty. N Eng J Med, 1994; 330: 956-961. 
2. EPILOG Investigators. Platelet glycoprotein IIb/IIIa receptor blockade and low-dose heparin during percutaneous coronary revascularization. N Eng J Med, 1997; 336: 1689-1696.

3. CAPTURE Investigators. Randomised placebo-controlled trial of abciximab before and during coronary intervention in refractory unstable angina: The CAPTURE Study. Lancet, 1997; 349: 1429-1435.

4. PRISM-PLUS Investigators. Inhibition of the platelet glycoprotein IIb/IIIa receptor with tirofiban in unstable angina and non-Q-wave myocardial infarction. N Eng J Med, 1998; 338: 1488-1497.

5. PRISM Investigators. A comparison of aspirin plus tirofiban with aspirin plus heparin for unstable angina. N Eng J Med, 1998; 338: 1498-1505.

6. Steg PG, James SK, Atar D et al. ESC Guidelines for the management of acute myocardial infarction in patients presenting with ST-segment elevation. Eur Heart J, 2012; 33: 2569-2619.

7. Davies MJ. Pathology of arterial thrombosis. Br Med Bull, 1994; 50: 789-802.

8. Kozinski M, Bielis L, Wisniewska-Szmyt J et al. Diurnal variation in platelet inhibition by clopidogrel. Platelets, 2011; 22: 579-587.

9. Koziński M, Bielis L, Wiśniewska-Szmyt J et al. Increased morning ADP-dependent platelet aggregation persists despite dual antiplatelet therapy in patients with first ST-segment elevation myocardial infarction: Preliminary report. Cardiol J, 2008; 15: 530-536.

10. Cox D, Aoki T, Seki J, Motoyama Y, Yoshida K. The pharmacology of the integrins. Med Res Rev, 1994; 14: 195-228.

11. Plow EF, D'Souza SE, Ginsberg MH. Ligand binding to GP IIb/ /IIIa: A status report. Semin Thromb Hemost, 1992; 18: 324-332.

12. Gawaz MP, Loftus JC, Bajt ML, Frojmovic MM, Plow EF, Ginsberg $\mathrm{MH}$. Ligand bridging mediates integrin alpha IIb beta 3 (platelet GPIIb/IIIa) dependent homotypic and heterotypic cellcell interactions. J Clin Invest, 1991; 88: 1128-1134.

13. Coller BS, Peerschke EI, Scudder LE, Sullivan CA. A murine monoclonal antibody that completely blocks the binding of fibrinogen to platelets produces a thrombastenic-like state in normal platelets and binds to glycoproteins IIb and/or IIIa. J Clin Invest, 1983; 72: 325-338.

14. Coller BS. A new murine monoclonal antibody reports an activation-dependent change in the conformation and/or microenvironment of the platelet glycoprotein IIb/IIIa complex. J Clin Invest, 1985; 76: 101-108.

15. Lefkovits J, Plow EF, Topol EJ. Platelet glycoprotein IIb/IIIa receptors in cardiovascular medicine. N Eng J Med, 1995; 332: 1553-1559.

16. Marciniak SJ Jr, Mascelli MA, Furman MI et al. An additional mechanism of action of abciximab: dispersal of newly formed platelet aggregates. Thromb Haemost, 2002; 87: 1020-1025.

17. Hantgan RR, Moussa SA. Inhibition of platelet-mediated clot retraction by integrin antagonists. Thromb Res, 1998; 89: 271-279.

18. Collet JP, Mishal Z, Soria J et al. Disaggregation of in vitro platelet-rich clots by abciximab increases fibrinogen exposure and promotes fibrinolysis. Arterioscler Thromb Vasc Biol, 2001; 21: $142-148$.

19. Romagnoli E, Burzotta F, Trani C, Biondi-Zoccai GG, Giannico F, Crea F. Rationale for intracoronary administration of abciximab. J Thromb Thrombolysis, 2007; 23: 57-63.

20. Tam SH, Sassoli PM, Jordan RE, Nakada MT. Abciximab (ReoPro, chimeric 7E3 Fab) demonstrates equivalent affinity and functional blockade of glycoprotein IIb/III and avb3 integrins. Circulation, 1998; 98: 1085-1091.
21. Byzova TV, Rabbani R, D'Souza SE, Plow EF. Role of integrin alpha(v) beta3 in vascular biology. Thromb Haemost, 1998; 80: 726-734.

22. Schwartz SM. Smooth muscle migration in atherosclerosis and restenosis. J Clin Invest, 1997; 100: 87-89.

23. Baron JH, Moiseevaa EP, de Bonoa DP, Abrams KR, Gershlick $\mathrm{AH}$. Inhibition of vascular smooth muscle cell adhesion and migration by c7E3 Fab (abciximab): A possible mechanism for influencing restenosis. Cardivasc Res, 2000; 48: 464-472.

24. Stouffer GA, Hu Z, Sajid M et al. Beta3 integrins are upregulated after vascular injury and modulate thrombospondin- and thrombin-induced proliferation of cultured smooth muscle cells. Circulation, 1998; 97: 907-915.

25. Blindt R, Bosserhoff AK, Zeiffer U, Krott N, Hanrath P, vom Dahl J. Abciximab inhibits the migration and invasion of human coronary artery smooth muscle cells. J Mol Cell Cardiol, 2000; 32 : 2195-2206.

26. EPISTENT Investigators. Randomised placebo-controlled and balloon-angioplasty controlled trial to assess safety of coronary stenting with use of platelet glycoprotein IIb/IIIa blockade. Lancet, 1998; 352: 87-92.

27. Mehilli J, Kastrati A, Schühlen H et al. Randomized clinical trial of abciximab in diabetic patients undergoing elective percutaneous coronary interventions after treatment with a high loading dose of clopidogrel. Circulation, 2004; 110: 3627-3635.

28. Iversen $\mathrm{AZ}$, Pedersen SH, Joens $\mathrm{C}$ et al. Impact of abciximab in diabetic patients with acute coronary syndrome who undergo percutaneous coronary intervention: results from a high-volume, single-center registry. J Invasive Cardiol, 2011; 23: 21-26.

29. Wu Y, Shi $\mathrm{Y}, \mathrm{Wu} \mathrm{H}$ et al. Efficacy and safety of abciximab in diabetic patients who underwent percutaneous coronary intervention with thienopyridines loading: A meta-analysis. PLoS One, 2011; 6: e20759.

30. The ERASER investigators. Acute platelet inhibition with abciximab does not reduce in-stent restenosis. Circulation, 1999; 100: 799-806.

31. De Luca L, Sardella G, De Persio G, Petrolini A, Fedele F. Impact of abciximab on coronary restenosis in diabetic patients undergoing elective paclitaxel-eluting stent implantation. A prospective, randomized, placebo-controlled study. Acute Card Care, 2008; 10: 93-99.

32. Valgimigli M, Percoco G, Malagutti P et al. Tirofiban and sirolimus-eluting stent vs abciximab and bare-metal stent for acute myocardial infarction: A randomized trial. JAMA, 2005; 4: 2109-2017.

33. Valgimigli M, Percoco G, Barbieri D et al. The additive value of tirofiban administered with the high-dose bolus in the prevention of ischemic complications during high-risk coronary angioplasty: The ADVANCE Trial. J Am Coll Cardiol, 2004; 44: 14-19.

34. Kim W, Jeong MH, Hong YJ et al. The long-term clinical results of a platelet glycoprotein IIb/IIIa receptor blocker (Abciximab: Reopro) coated stent in patients with coronary artery disease. Korean J Intern Med, 2004; 19: 220-229.

35. Kim W, Jeong MH, Kim KG et al. The clinical results of a platelet glycoprotein IIb/IIIa receptor blocker (abciximab: ReoPro)-coated stent in acute myocardial infarction. J Am Coll Cardiol, 2006; 47 : 933-938.

36. Kim SS, Hong YJ, Jeong MH et al. Two-year clinical outcome after abciximab-coated stent implantation in patients with coronary artery disease. Circ J, 2010; 74: 442-448.

37. Hong YJ, Jeong MH, Lee SR et al. Anti-inflammatory effect of abciximab-coated stent in a porcine coronary restenosis model. J Korean Med Sci, 2007; 22: 802-809. 
38. Sakuma T, Sari I, Goodman CN, Lindner JR, Klibanov AL, Kaul S. Simultaneous integrin alphavbeta3 and glycoprotein IIb/IIIa inhibition causes reduction in infarct size in a model of acute coronary thrombosis and primary angioplasty. Cardiovasc Res, 2005; 66: 552-561.

39. Simpson PJ, Todd RF, Fantone JC, Mickelson JK, Griffin JD, Lucchesi BR. Reduction of experimental canine myocardial reperfusion injury by a monoclonal antibody (anti-Mol, anti-CD11b) that inhibits leukocyte adhesion. J Clin Invest, 1988; 81: 624-629.

40. Lefer DJ, Shandelya SM, Serrano CV et al. Cardioprotective actions of a monoclonal antibody against CD-18 in myocardial ischemia-reperfusion injury. Circulation, 1993; 88: 1779-1787.

41. Jerome SN, Smith CW, Korthuis RJ. CD18-dependent adherence reactions play an important role in the development of the noreflow phenomenon. Am J Physiol, 1993; 264: 479-483.

42. Neumann FJ, Ott I, Gawaz M et al. Cardiac release of cytokines and inflammatory responses in acute myocardial infarction. Circulation, 1995; 92: 748-755.

43. Neumann FJ, Marx N, Gawaz M et al. Induction of cytokine expression in leukocytes by binding of thrombin-stimulated platelets. Circulation, 1997; 95: 2387-2394.

44. Neumann FJ, Zohlnhofer D, Fakhoury L, Ott I, Gawaz M, Schomig A. Effect of glycoprotein IIb/IIIa receptor blockade on platelet leukocyte interaction and surface expression of the leukocyte integrin Mac-1 in acute myocardial infarction. J Am Coll Cardiol, 1999; 34: 1420-1426.

45. Schuler P, Assefa D, Ylanne J et al. Adhesion of monocytes to medical steel as used for vascular stents is mediated by the integrin receptor Mac-1(CD11b/CD18; alphaM beta2) and can be inhibited by semiconductor coating. Cell Commun Adhes, 2003; 10: $17-26$

46. Schwarz M, Nordt T, Bode C, Peter K. The GP IIb/IIIa inhibitor abciximab (c7E3) inhibits the binding of various ligands to the leukocyte integrin Mac-1(CD11b/CD18, alphaMbeta2). Thromb Res, 2002; 107: 121-128.

47. Simon DI, Xu H, Ortlepp S, Rogers C, Rao NK. 7E3 monoclonal antibody directed against the platelet glycoprotein IIb/IIIa crossreacts with the leukocyte integrin Mac-1 and blocks adhesion to fibrinogen and ICAM-1. Arterioscler Thromb Biol, 1997; 17: 528-535.

48. Libby P, Ridker PM, Maseri A. Inflammation and atherosclerosis. Circulation, 2002; 105: 1135-1143.

49. Kozinski M, Krzewina-Kowalska A, Kubica J et al. Percutaneous coronary intervention triggers a systemic inflammatory response in patients treated for in-stent restenosis: Comparison with stable and unstable angina. Inflamm Res, 2005; 54: 187-193.

50. Kubica J, Kozinski M, Krzewina-Kowalska A et al. Combined periprocedural evaluation of CRP and TNF-alpha enhances the prediction of clinical restenosis and major adverse cardiac events in patients undergoing percutaneous coronary interventions. Int J Mol Med, 2005; 16: 173-180.

51. Lincoff AM, Kereiakes DJ, Mascelli MA et al. Abciximab supresses the rise in levels of circulating inflammatory markers after percutaneous coronary revascularization. Circulation, 2001; 104: 163-167.
52. Kubica J, Koziński M, Navarese EP et al. Updated evidence on intracoronary abciximab in ST-elevation myocardial infarction: A systematic review and meta-analysis of randomized clinical trials. Cardiol J, 2012; 19: 230-242.

53. Kubica A, Kozinski M, Navarese EP, Grzesk G, Goch A, Kubica J. Intracoronary versus intravenous abciximab administration in STEMI patients: overview of current status and open questions. Curr Med Res Opin, 2011; 27: 2133-2144.

54. Navarese EP, Kozinski M, Obonska $\mathrm{K}$ et al. Clinical efficacy and safety of intracoronary vs. intravenous abciximab administration in STEMI patients undergoing primary percutaneous coronary intervention: a meta-analysis of randomized trials. Platelets, 2012; 23: 274-281.

55. Koziński M, Grześk G, Kubica J. Optymalna terapia przeciwpłytkowa i przeciwzakrzepowa u pacjentów $\mathrm{z}$ ostrym zawałem serca Z uniesieniem odcinka ST. Kardiol Pol, 2012; 1: 206-212.

56. Pellicori P, Torromeo C, Barilla F et al. Intravenous versus intracoronary bolus of glycoprotein IIb/IIIa inhibitor administration during primary percutaneous coronary intervention on long-term left ventricular systolic and diastolic function. Cardiol J, 2013; 20; 310-317.

57. Bellandi F, Maioli M, Gallopin M, Toso A, Dabizzi RP. Increase of myocardial salvage and left ventricular function recovery with intracoronary abciximab downstream of the coronary occlusion in patients with acute myocardial infarction treated with primary coronary intervention. Catheter Cardiovasc Interv, 2004; 62: 186-192.

58. Thiele H, Schindler K, Friedenberger J et al. Intracoronary compared with intravenous bolus abciximab application in patients with ST-elevation myocardial infarction undergoing primary percutaneous coronary intervention: The randomized Leipzig immediate percutaneous coronary intervention abciximab IV versus IC in ST-elevation myocardial infarction trial. Circulation, 2008; 118: 49-57.

59. Prati F, Capodanno D, Pawlowski T et al. Local delivery versus intracoronary infusion of abciximab in patients with acute coronary syndromes. J Am Coll Cardiol Cardiovasc Interv, 2010; 3: 928-934.

60. Peerlinck K, De Lepeleire I, Goldberg M et al. MK-383 (L-700,462), a selective nonpeptide platelet glycoprotein IIb/IIIa antagonist, is active in man. Circulation, 1993; 88: 1512-1517.

61. Azar RR, Badaoui G, Sarkis A et al. Effect of high bolus dose tirofiban on the inflammatory response following percutaneous coronary intervention. Clin Cardiol, 2010; 33: 14-19.

62. Walters DL, Ray MJ, Wood P, Perrin EJ, Bett JH, Aroney CN. High-dose tirofiban with enoxaparin and inflammatory markers in high-risk percutaneuos intervention. Eur J Clin Invest, 2010; 40: 139-147.

63. Ercan E, Tenqiz I, Duman C, Onbasili OA, Baris N. Effect of tirofiban on C-reactive protein in non-ST-elevation myocardial infarction. Am Heart J, 2004; 147: 54-57.

64. Ueland T, Aukrust P, Omdal TR et al. Effect of eptifibatide on platelet-mediated inflammation in acute coronary syndromes. Int J Cardiol, 2011; 151: 385-387.

65. Mazaev AA, Naimushin YA, Masenko, Ruda MY, Mazurov AV. Eptifibatide does not suppress the increase of inflammatory markers in patients with non-ST-segment elevation acute coronary syndrome. J Thromb Thrombolysis, 2009; 27: 146-153. 